ous facts bearing upon it have been announced in its reports and bulletins.

(6) The work of increasing the supply of valuable fishes and other aquatic forms in the waters of the United States, whether by artificial propagation or by transplantation, although very successful, may be considered as yet in its infancy.

It must be remembered that the agencies which have tended to diminish the abundance of the fish have been at work for many years and are increasing in an enormous ratio. This, taken in connection with the rapid multiplication of the population of the United States, makes the work an extremely difficult one. If the general conditions remained the same as they were fifty years ago, it would be a very simple thing to restore the former equilibrium.

At that time, it must be remembered, the methods of preservation and of wholesale transfer, by means of ice, were not known, while the means of quick transportation were very limited. Hence a small number of fish supplied fully the demand, with the exception, of course, of species that were salted down, like the cod, the mackerel, and the herring (including the shad). Now, however, the conditions are entirely changed. The whole country participates in the benefits of a large capture of fish, and there is no danger of glutting the market, since any surplus can be immediately frozen and shipped to a distance, or held until the occurrence of a renewed demand.

Another impediment to the rapid accomplishment of the desired result is the absence of concurrent protective legislation of a sufficiently stringent character to prevent unnecessary waste of the fish during the critical period of spawning, and the erection or maintenance of impediments to their movements in reaching the spawning-grounds. This is especially the case with the shad and the salmon, where the simple construction of an impassable dam, or the erection of a factory discharging its poisonous waste into the water, may in a few years entirely exterminate a successful and valuable fishery.

It is to be hoped that public opinion will be gradually led up to the necessity of action of the kind referred to, and that year by year a continued increase in the fisheries will be manifested. Even if this does not occur as rapidly as some may hope, the experiments so far furnish the strongest arguments in favour of continuing the work for a reasonable time. A diminution that has been going on for fifty or more years is not to be overcome in ten, in view of the increasing obstacles already referred to.

Among the species an increase of which in their appropriate places and seasons is to be hoped for, in addition to those now occupying the attention of fish-culturists, are the cod, the halibut, the common mackerel, the Spanish mackerel, the striped bass, or rockfish, \&c.

One of the most important, and at the same time among the most promising, fish is the California trout, with which it is hoped to stock large areas of the country. Its special commendations are mentioned elsewhere in this Report.

Another fishery earnestly calling for assistance, and capable of receiving it, is that of the lobster, the decrease of which has been very marked. The experiments of the Fish Commission suggest methods by which the number can be greatly increased. Something, too, may be done with the common crab of the Atlantic coast and its transfer to the Pacific. Some kinds might also be advantageously brought to the eastern portion of the United States from the Pacific coast and from the European seas.

A subject of as much importance as any other that now occupies the attention of the Fish Commission is an increase in the supply of oysters. In no depariment of the American fisheries has there been so rapid and alarming a decrease, and the boasted abundance of this mollusk on the Atlantic coast, especially in Chesapeake Bay, is rapidly being changed to a condition of scarcity which threatens practical extermination, as is almost the case in England A fishing industry producing millions of dollars is menaced with extinction, and needs the most stringent measures for its protection.

The U.S. Fish Commission has been very fortunate, through its agents and assistants, in making important discoveries in connection with the propagation of the oyster, which are referred to hereafter in this Report; and it is proposed to establish several experimental stations for applying the discoveries thus made, so as to constitute a school of instruction and information to persons practically engaged in the business.

There are other shell-fish besides the oyster that will well repay the trouble of transplantation and multiplication. Among these are several species of clams belonging to the Pacific coast of the United States, which are much superior in size, in tenderness, and in excellence of flavour to those on the eastern coast. Most of these are natives of Puget Sound, and the completion of the Northern Pacific Railway is looked forward to as a convenient means of transferring them to Eastern waters. The coinmon clams of the Atlantic coast are also fair subjects of experiment.

\section{VOLCANIC DUST FROM NEW ZEALAND}

A SHORT time since, Sir Julius von Haast sent me a small packet of volcanic dust from New Zealand, and requested me to examine it. The dust fell on June Io of the present year (the day of the Tarawera eruption) at Matakava, Hicks Bay, I I 5 miles from the scene of the eruption. This dust is very fine, and, when regarded in the mass, is a dull, darkish gray colour. When examined under the microscope, it may be divided into-

(a) Bits of a more or less scoriaceous aspect-tiny lapilli, commonly almost opaque, being only translucent on thin edges-consisting of a somewhat brownish glass containing much disseminated ferrite. With reflected light they are a light to a darkish gray in colour, sometimes slightly reddish or brownish, with moderately rough surfaces. In size they usually vary from about 005 to .008 inch in the longest diameter; the former being the more common measurement ; the latter is but rarely exceeded, the largest fragment in the portion which I have examined being 012 inch in diameter; lapilli also occur of less than 005 inch.

(b) Chips, more or less transparent, generally not exceeding 005 inch in diameter, and of all dimensions downwards to the finest dust. The majority of these chips are glass, commonly quite colourless ; some of them contain bubbles, spherical, spheroidal, or more or less cylindrical. Sometimes these are quite $\mathrm{OoI}$ inch in longest diameter. Many chips show a ridgy surface, and are evidently formed by the destruction of a very frothy pumice like that of Krakatao. Some of the glass is of a light brown colour; occasionally it contains microliths of feldspar or trichites. The mineral chips are much less numerous than those of glass; the great majority of them are feldspar. Many of these are flat flakes apparently detached from a basal plane, but a few exhibit twinning. Some may be sanidine, but a plagioclastic feldspar is certainly present. The chips, however, are ill-suited for optical measurements, and the results which I have obtained are rather discordant. So far as I can come to a conclusion, I should say that the extinction-angles seem to indicate the not unfrequent presence of a feldspar which belongs rather to the oligoclase-albite group than to the labradorite-anorthite. I find very few indications of the presence of a pyroxenic constituent. One or two fragments are a greenish hornblende ; three or four in general appearance resemble small flakes of magnesia-iron micalying on their basal faces, but some of these show dichroism, and only extinguish in certain positions between crossed Nicols, so that they cannot be this mineral. As to 
their true nature I have not yet been able to decide; however, I think it probable some of the brown flakes are mica.

The result of my examination leads me to conclude that the dust is formed of material which was a glass wherein a porphyritic structure, on a large or a minute scale, was inconspicuous. This Matakava dust appears to agree generally with, though it differs varietally from, that described by Prof. Joly in NATURE (vol. xxxiv. $p$ 595), the main difference being that the biotite, which seems rather common in his samples, is rare in, if not absent from, the present one. I have not noticed sulphur, pyrite, or magnetite in a recognisable form.

It may be interesting to compare this dust with some samples projected from Cotopaxi, and described by myself (Proc. Roy. Soc. No. 231). These specimens came from various distances, ranging from twenty to sixty-five miles from the volcano. That which fell on the summit of Chimborazo (the most distant locality) consists of lapilli and chips ; the majority of the grains range from about - 00 I to 003 inch; a very few only attain to a diameter of - oI inch, and this is barely exceeded. In this dust, however the lapilli are comparatively rare, the chips of glass and mineral dominating, with a fair proportion of the latter. A reference to the above paper will show the difference between this ash, that from Krakatao, and the abovedescribed from New Zealand. This may be explained by the fact that a porphyritic structure is common in the lavas of Cotopaxi (as in the other summits of the district).

T. G. BONNEY

\section{NOTES}

We have to record the death of General John Theophilus Beaulieu, F.R.S., at the age of eighty-one years. He entered the Indian Army in 1820 as a lieutenant in the Bengal Engineers, and was for some time Superintending Engineer in the Public Works Department for the N.W. Provinces. Among other services to science and to India, General Beaulieu inaugurated the system of magnetic observations in India, and was the author of a book of logarithms of wide reputation. General Beaulieu was elected a Fellow of the Royal Society fifty years ago, and has served on its Council.

THE death is announced, at Berlin, of Dr. A. Fischer, so long resident at Zanzibar, and who has done so much for the exploration of the Kilimanjaro region.

M. Chancourtors, General Inspector of Mines in France, author of several works on geology, and Professor in the School of Mines, has died suddenly at Paris at the age of sixty-seven.

THE following are the probable arrangements for the meetings of the Society of Arts before Christmas:- "November 24, William Anderson, M.Inst.C.E., "Purification of Water by Agitation with Iron and by Sand Filtration." December I, adjourned discussion on the paper by Dr. C. Meymott Tidy, on "Sewage Disposal" (read April I4, I886). December 8, Major-General C. E. Webber, R.E., C.B., "Glow-Lamps, their Use and Manufacture." December I5, J. B. Marsh, "Cameo-cutting as an Occupation." There will be five courses of Cantor Lectures during the session:-(I) "Principles and Practice of Ornamental Design," by Lewis Foreman Day. (2) "Diseases of Plants, with special reference to Agriculture and Forestry," by T. L. W. Thudichum, M.D. (3) "Building Materials," by W. Y. Dent, F.C.S., F.I.C. (4) "Machines for Testing Materials, especially Iron and Steel," by Prof. W. C. Unwin. (5) "The Structure of Textile Fibres," by Dr. Frederick H. Bowman, F.L.S., F.G.S. Two Juvenile Lectures on "Soap Bubbles," by A. W. Reinold, F.R.S., will be given on Wednesday evenings, January 5 and 12,1887 . The meetings of the Colonial Section and of the Indian Section will not commence till after Christmas.

THE General Committee of the Society for the Prevention of Hydrophobia and Reform of the Dog Laws held its fourth meeting on Friday last at the offices, 50, Leicester Square, London, W.C., to consider a programme which had been drafted by a sub-committee and circulated among members and supporters. Mr. Victor Horsley, B.S., F.R.S., Secretary to the Commission on Hydrophobia, attended this meeting by invitation, and was unanimously elected a Member of Committee. Many letters were read expressing approval of the programme and regretting that the writers were unable to attend. Among the gentlemen who thus wrote were Dr. Drysdale, Prof. Fleming, Dr. Norman Kerr, Prof. E. Ray Lankester, Mr. Arthur Nicols, and Prof. Pritchard. The Honorary Secretary having made a financial statement of a satisfactory nature, the Chairman, Colonel R. H. Rosser, briefly explained the care and time given by the sub-committee to the programme, which was then discussed in detail, and ordered to be printed with some additions and alterations.

IT is intended, in Section III. of the Manchester Jubilee Exhibition, to exhibit the historical and modern methods adopted in the several branches of electro-metallurgy, such as gold, silver, platinum, nickel and copper plating, the purification of metals by electrolysis, and generally to illustrate the connection between electricity and chemistry.

INFORMATION has been received by the Board of Trade respecting the oyster fisheries of the Isle of Wight. The oyster grounds and breeding ponds of the Isle of Wight are as follows : -(I) Medina River; (2) Brading Harbour; (3) Newtown ; (4) Fishouse or Fishbourne. In 1867 the Isle of Wight Oyster Fishery Company was started, having the Medina River and Newtown Creek for its grounds. This oyster fishery is said to have done well until I871, when it was troubled by refuse and sewage discharged by mills at Newport, and a large quantity of the broods were destroyed. The Medina fishery is now for sale. About the year 1873 Major Boyle started a system for breeding oysters at Brading, but in 1876 the harbour works were commenced, and Major Boyle had to relinquish his ponds. The Harbour Board, however, still carry on the oyster breeding at Brading. They have six or seven ponds near St. Helens, which are estimated to contain five or six millions of oysters at the present time. As Brading is not suitable for fattening, the young oysters are sold to various growers to be laid down for one or two years to render them fit for food. Newtown Creek is the best fattening ground in the Isle of Wight, but the fishery company is now in liquidation through want of funds, and the business is in abeyance. At Fishhouse there has been a good fall of spat this last summer, but the ground is much disturbed by barges, which prevents the fishery from being fully developed. The oyster fishery is consequently not very prosperous. The creek, it may be mentioned, was recently cleared, and some sixty or seventy thousand oysters were transferred to Newtown to fatten in a pond placed at their disposal by the Newtown Company. Besides the oyster fishery companies above referred to, there are several fishermen who dredge for oysters at sea in the Solent, and particularly in Osborne Bay. The oysters dredged up are seldom fit for the market, and have usually been sold to one of the companies to be laid down and fattened.

IN Dr. B. W. Richardson's recent Cantor Lectures on "Animal Mechanics," speaking of the mechanism of the heart, he described the number of the pulsations of the heart in different animals-in fish, frog, bird, rabbit, cat, dog, sheep, horse-and made a few comments on the remarkable slowness of the heart -40 strokes per minute-in the horse. Then the number of 